\title{
Socio-Demographic Distribution of Patients with Fixed Dental Prosthesis in a Developing Economy
}

\section{Joan Emien Enabulele* and Julie Omo}

Department of Restorative Dentistry, School of Dentistry, University of Benin, Benin City, Edo State, Nigeria

${ }^{*}$ Corresponding author: Joan Emien Enabulele, Department of Restorative Dentistry, School of Dentistry, University of Benin, Benin City, Edo State, Nigeria, Tel: +234803727581; E-mail: emien.enabulele@uniben.edu

Received date: April 28, 2018; Accepted date: May 15, 2018; Published date: May 22, 2018

Copyright: (C) 2018 Enabulele JE, et al. This is an open-access article distributed under the terms of the creative Commons Attribution License, which permits unrestricted use, distribution and reproduction in any medium, provided the original author and source are credited.

Citation: Enabulele JE, Omo J (2018) Socio-Demographic Distribution of Patients with Fixed Dental Prosthesis in a Developing Economy. Periodon Prosthodon. Vol.4 No.1:06.

\section{Abstract}

Background: Socio-demographic characteristics influencing the prevalence of dental restorations varies from country to country, hence this study sought to evaluate the socio-demographic distribution of patients with fixed dental prosthesis at a tertiary hospital in Nigeria.

Method: This was a retrospective cross-sectional study of all patients who received fixed dental prosthesis over a 5year period. he data of interest retrieved from patients' records were demographic characteristics (age, gender, marital status, occupation), type of fixed prosthesis fabricated and teeth for which they were fabricated as well as indication for the provision of the fixed prostheses. Data collected was subjected to statistically analysis using IBM SPSS version 21.0.

Results: A total of 256 patient records with the desired information were used for the study. The patients' age ranged from 18 to 83 years with a mean age of $38.86 \pm$ 15.86 years. There was a decline in number of patients who received fixed prosthesis as age increased with those $\leq 30$ years of age recording the highest frequency. Skilled workers accounted for the majority $(35.2 \%)$ of the patients while dependent and professionals accounted for $32.0 \%$ and $22.7 \%$ respectively. More than half $(52.0 \%)$ of the patients were married. A higher proportion of females had crowns provided for them while a higher proportion of males had fixed partial denture provided for them and this was statistically significant

Conclusion: Fixed dental prosthesis is sought by patients with higher socioeconomic status and young adults with a higher prevalence of males demanding fixed partial denture and females, single crowns.

Keywords: Fixed dental prosthesis; Demographics; Developing economy

\section{Introduction}

A dental restoration is a general term used for any material or prosthesis that replaces the lost tooth structure, teeth, or oral tissues [1]. Dental prosthesis could either be fixed or removable. It has been postulated that socio-demographic characteristics influencing the prevalence of dental restorations varies from country to country [2]. This variability may be influenced by ability to afford this type of treatment, accessibility of treatment and attitudes toward it [3].

A study reported a steady rise in the numbers of fixed dental prosthesis placed over a 40-year period with the 31-40 years age group receiving the greatest number of crowns [4] This was similar to findings of the UK Adult Dental Health Survey in 1998 [5]. which identified people aged 45-54 as having the most crowns. However, another study reported no variation by age group or sex to number of fixed dental prosthesis but there was association with other sociodemographic variables such as race and socioeconomic class [3]. The role of socioeconomic status in the utilization of dental prosthesis has been highlighted [6-8].

Although a high proportion of individuals require some sort of dental prosthesis, treatment involving the use of dental prosthesis is infrequent in developing countries [9]. Social and geographical variations in dental prosthetic replacement may be associated with differences in both patients' and dentists' attitudes towards oral health as well as socioeconomic status [10]. Hence this study aimed at evaluating the sociodemographic distribution of patients with fixed dental prosthesis at a tertiary hospital in Nigeria.

\section{Methodology}

This was a retrospective cross-sectional study of all patients who received fixed dental prosthesis at the Restorative clinic of the University of Benin, Benin City, Edo State, Nigeria, over a period of 5 years (July 2012 to August 2017). The data of interest retrieved from patients' records were demographic characteristics (age, gender, marital status, occupation), type of fixed prosthesis fabricated and teeth for which they were 
fabricated as well as indication for the provision of the fixed prostheses. The standard International Labour occupational classification system modified by Enabulele and Obuekwe11 was used to classify occupation into five socioeconomic groups: professionals and managerial officers and retirees of this type (e.g., Doctors, lawyers), skilled Workers (e.g., Civil servants), Semi-skilled Workers (e.g., Artisans), Unskilled workers (Traders) and dependents (Unemployed individuals and Students).

Data collected was subjected to statistically analysis using IBM SPSS version 21.0. Analysis carried out were descriptive analysis in the form of mean, range and standard deviation. Cross tabulations were also performed along with Chi square to determine any associations between variables with $p$ set at 0.05 .

\section{Results}

A total of 305 patients were identified by the records of the department to have received fixed dental prosthesis over the period of the study. However, only 256 patient records with the desired information were used for the study giving a retrieval rate of $83.9 \%$. The patients' age ranged from 18 to 83 years with a mean age of $38.86 \pm 15.86$ years. There was a decline in number of patients who received fixed prosthesis as age increased with those $\leq 30$ years of age recording the highest frequency (42.6\%). More than half $(52.7 \%)$ were females with a male female ratio of $1: 1.12$. Skilled workers accounted for the majority $(35.2 \%)$ of the patients while dependent and professionals accounted for $32.0 \%$ and $22.7 \%$ respectively. More than half $(52.0 \%)$ of the patients were married (Table 1).

A total of 305 patients were identified by the records of the department to have received fixed dental prosthesis over the period of the study. However, only 256 patient records with the desired information were used for the study giving a retrieval rate of $83.9 \%$. The patients' age ranged from 18 to 83 years with a mean age of $38.86 \pm 15.86$ years. There was a decline in number of patients who received fixed prosthesis as age increased with those $\leq 30$ years of age recording the highest frequency $(42.6 \%)$. More than half $(52.7 \%)$ were females with a male female ratio of 1:1.12. Skilled workers accounted for the majority (35.2\%) of the patients while dependent and professionals accounted for $32.0 \%$ and $22.7 \%$ respectively. More than half $(52.0 \%)$ of the patients were married (Table 1).

A total of 305 patients were identified by the records of the department to have received fixed dental prosthesis over the period of the study. However, only 256 patient records with the desired information were used for the study giving a retrieval rate of $83.9 \%$. The patients' age ranged from 18 to 83 years with a mean age of $38.86 \pm 15.86$ years. There was a decline in number of patients who received fixed prosthesis as age increased with those $\leq 30$ years of age recording the highest frequency $(42.6 \%)$. More than half $(52.7 \%)$ were females with a male female ratio of 1:1.12. Skilled workers accounted for the majority (35.2\%) of the patients while dependent and professionals accounted for $32.0 \%$ and $22.7 \%$ respectively. More than half $(52.0 \%)$ of the patients were married (Table 1).

Table 1 Socio-demographic characteristics of the patients.

\begin{tabular}{|c|c|c|}
\hline Characteristics & Frequency & Percent \\
\hline \multicolumn{3}{|l|}{ Age group (years) } \\
\hline$\leq 30$ & 109 & 42.6 \\
\hline $31-49$ & 84 & 32.8 \\
\hline $50-69$ & 50 & 19.5 \\
\hline$\geq 70$ & 13 & 5.1 \\
\hline \multicolumn{3}{|l|}{ Gender } \\
\hline Male & 121 & 47.3 \\
\hline Female & 135 & 52.7 \\
\hline \multicolumn{3}{|l|}{ Occupation } \\
\hline Professional & 58 & 22.7 \\
\hline Skilled worker & 90 & 35.2 \\
\hline Semi-skilled worker & 4 & 1.6 \\
\hline Unskilled worker & 22 & 8.6 \\
\hline Dependent & 82 & 32 \\
\hline \multicolumn{3}{|l|}{ Marital status } \\
\hline Single & 123 & 48 \\
\hline Married & 133 & 52 \\
\hline Total & 256 & 100 \\
\hline
\end{tabular}

More than half $(51.2 \%)$ of the patients received fixed prostheses fabricated for the anterior teeth (Figure 1). Less than half $(42.6 \%)$ of the patients had fixed prosthesis fabricated for their incisors while $12.5 \%$ and $15.6 \%$ had fixed prosthesis fabricated for their premolars and molars respectively Canines were the teeth with the least $(0.4 \%)$ proportion of fixed prostheses provided for. Some patients had a combination of teeth provided with fixed prostheses represented by $9.4 \%$. Majority $(73.0 \%)$ of the patients received fixed prosthesis on their maxillary teeth (Figure 2). The number of units of fixed prosthesis received by the patients ranged from 1 to 7 with a mean number of $1.70 \pm 1.22$ units. Most (66.8\%) of the patients received single unit fixed prosthesis while $33.2 \%$ received multiple units. Majority (80.5\%) received crowns while $19.5 \%$ received fixed partial dentures. 


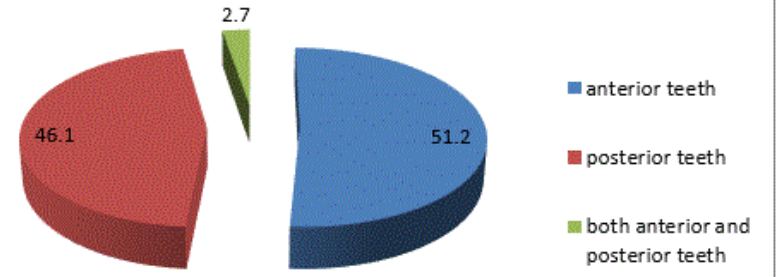

Figure 1 distribution of fixed prosthesis by tooth type.

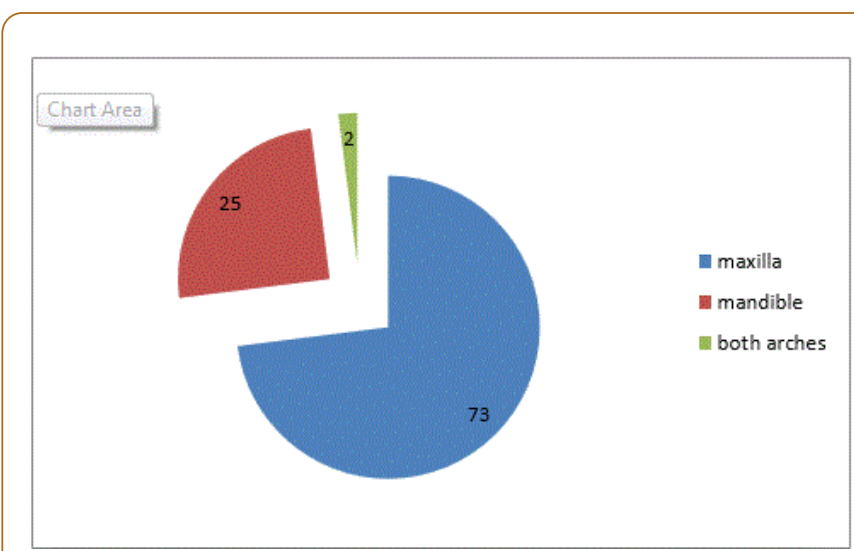

Figure 2 distribution of fixed prosthesis by arch.

Table 2 depicts the association between socio demographic characteristics of the patients and teeth that received fixed prostheses. There was statistically significant association between the age group, occupation as well as the marital status of the patients and the type of teeth that the fixed prostheses were fabricated for. A higher proportion (60.6\%) of patients' $\leq 30$ years of age had fixed prostheses provided for their anterior teeth. There was a decrease in fixed prostheses provided for anterior teeth with increase in age. The reverse was the case with posterior teeth as there was an increase in provision of fixed prostheses with increase in age $(p=0.05)$. A higher proportion of unskilled workers and dependents had fixed prostheses provided for their anterior teeth while a higher proportion of professionals and skilled workers had fixed prostheses provided for their posterior teeth $(p=0.034)$. A higher proportion of patients who were unmarried had fixed prostheses provided for their anterior teeth while a higher proportion of patients who were married had fixed prostheses provided for their posterior teeth $(p=0.005)$.

A higher proportion of females had crowns provided for them while a higher proportion of males had fixed partial denture provided for them and this was statistically significant $(p=0.02)$

Table 2 Association between the age, occupation and marital status of the patients and the type of teeth fixed prosthesis was provide for.

\begin{tabular}{|c|c|c|c|c|}
\hline \multirow[b]{2}{*}{ Characteristics } & \multicolumn{3}{|c|}{ Teeth type } & \multirow[b]{3}{*}{$\mathrm{n}(\%)$} \\
\hline & $\begin{array}{l}\text { Anterior } \\
\text { teeth }\end{array}$ & $\begin{array}{l}\text { Posterior } \\
\text { teeth }\end{array}$ & Combination & \\
\hline & $\mathrm{n}(\%)$ & $\mathrm{n}(\%)$ & $\mathrm{n}(\%)$ & \\
\hline Age group & & & & $P=0.05$ \\
\hline$\leq 30$ & $66(60.6)$ & $42(38.5)$ & $1(0.9)$ & $\begin{array}{l}109 \\
(100.0)\end{array}$ \\
\hline $31-49$ & $43(51.2)$ & $38(45.2)$ & $3(3.6)$ & $\begin{array}{l}84 \\
(100.0)\end{array}$ \\
\hline $50-69$ & $17(34.0)$ & $31(62.0)$ & $2(4.0)$ & $\begin{array}{l}50 \\
(100.0)\end{array}$ \\
\hline$\geq 70$ & $5(38.5)$ & $7(53.8)$ & $1(7.7)$ & $\begin{array}{l}13 \\
(100.0)\end{array}$ \\
\hline Occupation & & & & $\begin{array}{l}P=0.03 \\
4\end{array}$ \\
\hline Professionals & $22(37.9)$ & $35(60.3)$ & $1(1.7)$ & $\begin{array}{l}58 \\
(100.0)\end{array}$ \\
\hline Skilled workers & $40(44.4)$ & $47(52.2)$ & $3(3.3)$ & $\begin{array}{l}90 \\
(100.0)\end{array}$ \\
\hline $\begin{array}{l}\text { Semi-skilled } \\
\text { workers }\end{array}$ & $2(50.0)$ & $2(50.0)$ & $0(0.0)$ & $\begin{array}{l}4 \\
(100.0)\end{array}$ \\
\hline Unskilled workers & $17(77.3)$ & 4 (18.2) & $1(4.5)$ & $\begin{array}{l}22 \\
(100.0)\end{array}$ \\
\hline Dependents & $50(61.0)$ & $30(36.6)$ & $292.4)$ & $\begin{array}{l}82 \\
(100.0)\end{array}$ \\
\hline Marital status & & & & $\begin{array}{l}P=0.00 \\
5\end{array}$ \\
\hline Single & $74(60.2)$ & $44(35.8)$ & $5(4.1)$ & $\begin{array}{l}123 \\
(100.0)\end{array}$ \\
\hline Married & $57(42.9)$ & $74(55.6)$ & $2(1.5)$ & $\begin{array}{l}133 \\
(100.0)\end{array}$ \\
\hline Total & $\begin{array}{l}131 \\
(51.2)\end{array}$ & $\begin{array}{l}118 \\
(46.1)\end{array}$ & $7(2.7)$ & $\begin{array}{l}256 \\
(100.0)\end{array}$ \\
\hline
\end{tabular}

\section{Discussion}

Fixed dental prostheses are treatment/restorations for the replacement of missing tooth structure, teeth, or oral tissues. A previous study reported the mean age of patients demanding fixed dental prosthesis to be $31 \pm 10.2$ years, a finding lower than that observed in this study [12]. The demand for fixed dental prosthesis has been reported to be higher among males than females and this was contrary to the findings of this study [8]. However, a study by Ogunrinde et al. had similar gender disposition with this study [13]. Females tend to be more particular and apprehensive about their 
appearance and may tend to demand fixed prostheses treatment to replace lost dental tissues in Table 3 [14,15].

Table 3 Association between gender of the patients and type of prostheses provided.

\begin{tabular}{|l|l|l|l|}
\hline \multicolumn{2}{|l|}{ Prostheses } & \\
\hline Gender & Crown & Fixed partial denture & Total \\
\hline & $\mathrm{n}(\%)$ & $\mathrm{n}(\%)$ & $\mathrm{n}(\%)$ \\
\hline Male & $90(74.4)$ & $31(25.6)$ & $\begin{array}{l}121 \\
(100.0)\end{array}$ \\
\hline Female & $116(85.9)$ & $19(14.1)$ & $\begin{array}{l}135 \\
(100.0)\end{array}$ \\
\hline Total & $206(80.5)$ & $50(19.5)$ & $\begin{array}{l}256 \\
(100.0)\end{array}$ \\
\hline $\mathrm{P}=0.02$ & & & \\
\hline
\end{tabular}

It had been reported that higher socioeconomic class was associated with the demand for fixed dental prostheses [8]. The professionals and skilled workers in this study belong to the higher socioeconomic cadres and accounted for the majority of those who demanded treatment for fixed prosthesis. Fixed dental prostheses are more expensive with regards to financial cost than their removable counterparts.

Aesthetics is one of the reasons why missing tooth parts and teeth are replaced. This becomes imperative and foremost when the tooth to receive the prostheses is an anterior tooth which is prominent during smiling and speech. The anterior teeth represent one's personality, presentation, carriage and aesthetics when compared to the posterior teeth. Hence, more than half of the patients had anterior fixed prostheses treatment done. Among the teeth in the dental arch the canine is a corner tooth and one of the strongest teeth. Hence one of the least extracted teeth and possibly the reason why it was the teeth that received the least proportion of fixed prostheses $[16,17]$.

Maxillary fixed prosthesis is more predominant than mandibular fixed prosthesis a finding similar to previous studies $[2,18]$. This maybe because of the prominence of the maxilla making it more susceptible to trauma and more conspicuous when there is a pathology [18].

It has been observed that older people were more satisfied with their dental appearance than younger people [19]. This suggests that the appearance of the teeth is not as important for older individuals as compared to the younger individuals $[18,20]$. Hence, it was observed that a higher proportion of patients' $\leq 30$ years of age had fixed prostheses provided for their anterior teeth when compared with the older age group. Furthermore, this is the age group most prevalent to dental trauma and with consequent damage to the anterior teeth which is prominent in terms of aesthetics [21,22].

There was an increase in provision of fixed prostheses in posterior teeth with increasing age. As people age, there is an increase in loss of posterior teeth which may be associated with the predisposition of older patients to periodontal diseases and caries $[23,24]$. Furthermore, the posterior teeth function mainly for mastication, hence the need for replacement.

Cost, indications, clinical findings, dentist and patientimmanent factors are some of the features that affect the choice of treatment available to patients [15]. The treatment decision with single metal ceramic crowns has most often been preceded by a large restoration of the tooth or fractured restoration or tooth while treatment with fixed bridges frequent reasons were extractions of the tooth/teeth or replacement of an existing denture [25]. It was observed that a higher proportion of females had crowns provided for them while a higher proportion of males had fixed partial denture provided for them. This may be because the male gender has been associated with higher prevalence of partial edentulism [26].

In conclusion, fixed dental prosthesis are sought by patients with higher socioeconomic status and young adults with a higher prevalence of males demanding fixed partial denture and female's single crowns.

\section{References}

1. Nassani MZ, Locker D, Elmesallati A (2009) Dental health state utility values associated with tooth loss in two contrasting cultures. J Oral Rehab 36: 601-609.

2. Stankiewicz NR, Wilson PR (2000) A survey of the distribution and types of full crowns prescribed in Melbourne, Australia. Aust Dent J 45: 193-197.

3. Dolan TA, Gilbert GH, Duncan RP, Foerster U (2001) Risk indicators of edentulism, partial tooth loss and prosthetic status among black and white middle-aged and older adults. Comm Dent Oral Epidemiol 29: 329-340.

4. Farrell TH, Dyer MRY (1989) The provision of crowns in the general dental services 1948-1988. Br Dent J 167: 399-403.

5. Pine CM, Pitts JG, Steele JG, Nunn JN, Treasure E (2001) Dental restorations in adults in the UK in 1998 and the implications for the future. Br Dent J 190: 4-8.

6. Khalifa N, Allen PF, Abu-bakr NH, Abdel-Rahman ME (2012) Factors associated with tooth loss and prosthodontics status among Sudanese adults. J Oral Sci 54: 303-312.

7. Esan TA, Olusile AO, Akeredolu PA, Esan AO (2004) Sociodemographic factors and edentulism: the Nigerian experience. BMC Oral Health 4: 3.

8. Enabulele JE, Omo JO (2016) Socio-demographic determinants of demand for fixed and removable partial dentures. Inter J Biomed Health Sci 12: 19-23.

9. Shigli K, Hebbal M, Angadi GS (2009) Prosthetic status and treatment needs among patients attending the prosthodontics department in a dental institute in India. Eur J Prosthodont Restor Dent 17: 85-89.

10. McGrath C, Bedi R (2002) Severe tooth loss among UK adults who goes for oral rehabilitation. J Oral Rehab 29: 240-244.

11. Enabulele JE, Obuekwe ON (2017) Prevalence of caries and cervical resorption on adjacent second molar as an effect of impacted third molar. J Oral Maxillofac Surg Med Pathol 29: 301-305. 
12. Idrees N, Ghani F (2011) Demands, needs, expectations, patterns and reasons among patients for treatment with fixed dental prostheses. J Postgrad Med 22: 4.

13. Ogunrinde JT, Gbadebo SO, Sulaiman AO (2015) Trend in prosthetic rehabilitation of partially edentulous patients in a Nigerian teaching hospital. J West Afr Coll Surg 5: 84-99.

14. Enabulele JE, Omo JO (2017) Self-perceived satisfaction with dental appearance and desired treatment to improve aesthetic. African J Oral Health 7: 4-10.

15. Al-Quaran FA, Al-Ghalayini RF, Al-Zubi BN (2011) Single-tooth replacement: factors affecting different prosthetic treatment modalities. BMC Oral Health 11: 34.

16. Jafarian M, Etebarian A (2013) Reasons for extractions of permanent teeth in general dental practices in Tehran, Iran. Med Princ Pract 22: 239-244.

17. Odai CD, Azodo CC, Ehizele AO, Braimoh OB, Obuekwe ON (2011) Pattern of tooth extraction among adult patients attending a general dental practice in Benin City. Annals Biomed Sci 10: 1 .

18. Sede MA, Enabulele JE (2016) Types and materials used for fabrication of fixed dental prostheses at a Nigerian tertiary healthcare center. Tanz Dent J 19: 38-42.
19. Vallittu P, Vallittu A, Lassila V (1996) Dental aesthetics-a survey of attitudes in different groups of patients. J Dent 24: 335-338.

20. Alkhatib MN, Holt R, Bedi R (2005) Age and perception of dental appearance and tooth color. Gerodontol 22: 32-36.

21. Omo JO, Sede MA (2016) Sociodemographic determinant of usage of removable partial denture in a tertiary hospital: A retrospective study. Tropical Dent J 39: 54-60.

22. Brullmann D, Schulze RK, d'Hoedt B (2011) The treatment of anterior dental trauma. 'Dtsch Arztebl Int 108: 34-35.

23. Esan TA, Olusile AO, Ojo MA, Udoye Cl, Oziegbe EO (2010) Tooth loss among Nigerians treated in teaching hospitals: A national pilot survey. J Contemporary Dental Practice 11: 1-10.

24. Saheeb BD, Sede MA (2013) Reasons and pattern of tooth mortality in a Nigerian Urban teaching hospital. Ann Afr Med 12: 110-114.

25. Näpänkangas R (2003) Fixed metal ceramic prostheses: Treatment need, complications and survival of conventional fixed prosthodontics.

26. Enabulele JE, Eregie UJ, Omo JO (2016) Age and gender pattern of partial edentulism. Nig J Restor Dent 1: 32-36. 